\title{
Research on Development of College Physical Education under the Perspective of Sino-Russian Joint School-running
}

\author{
Changzhu Li \\ School of Physical Education \\ Heihe University \\ Heihe, Heilongjiang, China 164300
}

\begin{abstract}
With the development of China's education modernization, the internationalization level of China's collegerunning is improved constantly. Under this background, SinoRussian joint school-running has developed rapidly. The SinoRussian joint school-running is conducive to the introduction of the high quality education resources from Russia, and perform the reform and development of physical education in China; it is advantageous for China to form the verified and balanced international school-running pattern. To improve the quality and level of the Sino-Russian joint school-running and promote the development of physical education in colleges and universities, the physical education concept shall be changed, and, and adopt the scientific physical education mode, lay a good language foundation, accurately grasp the market demand, innovate the training mode, pay attention to process evaluation, and emphasize physical and mental health.
\end{abstract}

Keywords-Sino-Russian joint school-running; college physical education; teaching development

\section{INTRODUCTION}

At present, a comprehensive strategic partnership between China and Russia has already been formed, and the relationship between the two countries is kept very well. The good political relations have promoted the exchanges and cooperation between China and Russia in terms of culture and education. Under such a background, the colleges and universities jointly run by China and Russia are developed. On the other hand, various colleges and universities begin to recruit foreign students due to funding difficulties in Russia. All of these have promoted the education exchanges between China and Russia.

\section{CURRENT SituAtion OF COLLEGE PHYSiCAL} EDUCATION UNDER SINO-FOREIGN JOINT SCHOOL-RUNNING

\section{A. Current Situation of Physical Education Motivation}

Physical education motivation is one of the important factors influencing physical education, having a significant effect on students' learning. It is the internal drive for students' learning. In general, most of the students recognize the normal function of physical education, but have insufficient understanding of physical education's special value orientation.

This paper is the phased research achievement of funding project of the scientific research by young top talents in Heihe University .
Boys have no such strong behavior and high level as girls. Some students' learning motivation is to obtain credits and complete their studies. Overall, the students are positive in physical education. Only a few students are negative. Teachers should adapt to this kind of situation in teaching, and adopt the teaching mode with strong self-determination and openness, to provide students with more opportunities to put their subjective initiative into good use, enabling them to learning independently and create learning. As for the students with weak learning motivation, teachers should strengthen their guidance, and take various measures to stimulate their learning motivation.

\section{B. Current Situation in Terms of Interest in Physical Education}

Differences exist in students' interest in physical education in terms of gender, but on the whole, they all have a wide range of interest. The physical activities with strong antagonism and competitiveness are the boys' favourite, while girls prefer the physical activities with weak antagonism and strong entertaining and without direct contact. Both boys and girls like the foreign physical activities such as kickboxing and boxing, which are the activities they have in common. And there is reason for such situation. Students know that physical activity is good for them, but some students are crazy about the foreign things. So, teachers should consider the different interest of different gender in teaching, and they can introduce in some foreign physical activities as appropriate.

\section{Current Situation of Physical Education}

In the colleges jointly run by China and Russia, most of the physical education teachers have bachelor degree, and a small number of them have master degree and senior title. The faculty structure is young. As for the teachers' foreign language level, more than half of the teachers haven't passed the CET 4. As for professional skills, most of the teachers' professional skill is very good and can master more than four skills. And with respect to the enthusiasm of scientific research, physical education teachers have high enthusiasm, but their research level is generally low. In addition, there is another problem of physical education teachers, namely, there are more part-time teachers and less full-time teachers; some teachers are outgoing with positive thinking, and they can 
communicate with students very well, but lack of experience in teaching. Teachers' scientific research mainly focuses on domestic physical education study, involving little of foreign physical education study. Foreign language level has affected physical education teachers' ability of participating in the international scientific research, which has also brought adverse effects to the implementation of bilingual teaching.

\section{Current Situation of Physical Education Environment}

The colleges' physical education environment needs to be improved. The sports equipment and site in many schools can just only adapt to the needs of teaching, even a few schools cannot provide enough space and equipment for the teaching. There are many reasons for this situation. The national investment is insufficient; blind expansion of the colleges run cooperatively make the number of students grow, but campus construction lags behind; the number of physical education teachers are few, which cannot fully meet the needs of school teaching.

\section{NECESSITY OF SINO-RUSSIAN JOINT SCHOOL-RUNNING}

China and Russia are neighbors, and both of them are the important countries in northeast Asia and the permanent members of Security Council, sharing many common interests in regional and international affairs. In the 21st century, SinoRussian relations maintain good momentum and the cooperation between is strengthened constantly. People of China and Russia should understand and learn from each other, as well as complement each other for common development and progress. Therefore, it is necessary to carry out SinoRussian joint school-running.

\section{A. Sino-Russian Joint School-running Is Conducive to the Introduction of the High Quality Education Resources from Russia and the Promotion of Reform and Development of Physical Education in China}

With more and more attention being paid to education and the increasing investment in education, higher education in China has got rapid development. But because of the low starting point, so currently, there is still a gap between China's colleges and universities and the developed countries in terms of curriculum design, teaching level and teaching material development, and lack of science and technology innovation ability. The joint school-running with Russia can introduce in new teaching methods and curriculum structure, which is conducive to update our knowledge structure, optimize the teaching staff as well as strengthen teacher's exchange and cooperation between China and Russia. Under the mode of Sino-Russian joint school-running, we can invite teachers, experts and scholars of Russia to China for scientific research and teaching activities, and teachers from China can also go to Russian colleges for exchanges and learning, to learn their scientific knowledge and research skills and experience. This is helpful for Chinese teachers to learn Russian teaching and scientific research ability and technology, shortening the gap between China' education level and the world's advanced level of education. Under the mode of Sino-Russian joint schoolrunning, we can cultivate talents of various levels, establish interdisciplinary and emerging disciplines in colleges and universities, and carry out international cooperation research projects, to serve economic and social development.

\section{B. Sino-Russian Joint School-running Is Beneficial to Form the Pattern of Diversified and Balanced International School-running Pattern}

For a long time, most of the countries those carry out joint school-running with China are European and American countries, and China is at a disadvantage position in the negotiations. If the Sino-Russian joint school-running can be carried out very well, then our over-reliance on European and American countries can be reduced and the bargaining power can be increased, to lower our costs and expenses in joint school-running. The higher education level of Russia takes the leading position internationally. And Russia has many internationally renowned universities, which can be said a science and education power. With strong scientific research foundation, Russia has a first-class level of education. And the research in some areas cannot be underestimated. Moreover, it has some of the world's leading technology. Second, compared with the developed countries from Europe and the United States, the tuition of higher education in Russia is relatively low, which is more suitable for Chinese families. Russian college diploma is acknowledged in the European and American countries. Sino-Russian joint school-running can save the school-running cost for China and improve the teaching quality. The eastern provinces can carry out joint school-running with European countries and the United States, the central and western provinces should conduct joint schoolrunning with Russia, thus the scientific and rational international joint-school running pattern can be formed.

\section{RESEARCH ON DEVELOPMENT OF COLLEGE PHySiCAL} EDUCATION UNDER THE PERSPECTIVE OF SINO-RUSSIAN JOINT SCHOOL-RUNNING

\section{A. Shift the Physical Education Concept}

The purpose of physical education is stipulated in the Physical Education Curriculum Guiding Outline for Institutes of Higher Learning in China, namely to promote physical wellbeing and improve physical quality. Therefore, colleges and universities should adhere to the concept of health physical education to conduct physical education. In colleges and universities jointly run by China and Russia, there shall be advanced physical education concept, which can satisfy students' needs to enhance physical fitness and can really enhance the physical quality of students from China and Russia.

Health physical education not only pursues physical fitness, but also includes the cultivation of psychological health and social adaptability.

Colleges and universities should not only focus on the improvement of students' physical quality, but also shall keep their mental health and improve their social adaptation ability. The goal of physical education reform is to fully enhance the students' ability of sports. Colleges and universities should cultivate and improve students' sports skills on the one hand, and on the other hand, they shall also involve emotion 
regulation and cognition ability into the scope of training. Emotion regulation is to adjust the students' personal feelings, and help them form the cooperation consciousness and collective consciousness in sports activities. Students' cognitive abilities include the cognition to traditional physical health, rehabilitation and health care, as well as the cognition to the appreciation and evaluation of physical culture and common sense.

\section{B. Adopt the Scientific Physical Education Mode}

In the case of Sino-Russian joint school-running, China's traditional physical education mode is facing new problems, so new teaching mode shall be adopted. There are three new and suitable physical education modes, namely the teaching method combining China and Russia, Russian teaching method used for China and loose teaching method.

1) Teaching method combining China and Russia: Refers to draw lessons from Russian teaching method's advantages and strengths, and meanwhile retain the essence of Chinese traditional teaching methods, combining the two organically to achieve the effect of learning widely from others' strong points. Colleges and universities of both sides can negotiate to change the traditional teaching method, reset the teaching concept, improve teaching methods and optimize curriculum arrangement. This method not only conforms to the actual situation of physical education of China's colleges and universities, but also has absorbed the merits of Russian physical education, which is a very scientific method.

2) Russian teaching method used for China is to adopt the teaching method of Russia in teaching process: It requires the introduction of Russian physical education courses and teaching materials, Russian education concept, teaching means and teaching method, and requires introducing Russian physical education teachers to China to teach. This method enables domestic students to accept the good foreign education, saving students' study costs. The introduced teachers can improve the physical education and inject new vitality to the reform and development of college physical education.

3) Loose teaching method: Loose teaching method is mainly achieved by exchanging teachers, which is not only a teaching method, but also a means of communication. Specifically, the Chinese teachers are required to be assigned to Russia to give lectures, at the same time, invite Russia's teachers to carry out teaching activities in China. In addition, it can also be carried out in the form of further study. Chinese physical education teachers go to Russia to learn and absorb the advantage and experience of Russian teaching methods, and then apply to the domestic teaching. Loose teaching includes not only teacher exchanges, but also the exchanges and communication between students. Domestic colleges and universities can send exchange students to study and practice in Russia, enabling them to experience the foreign teaching style.

\section{Lay a Good Language Foundation}

China and Russia have signed the medium and long term cooperation plan of northeast China and Russian Far East and Siberia in 2009. The signing of this cooperation agreement has brought new opportunities for cooperation between China and Russia, also provided opportunity for the education exchanges between the two countries. Under the condition of SinoRussian joint school-running, colleges and universities will introduce Russian physical education teachers. But Russian teachers speak Russian, while Chinese students speak Chinese, so differences exist between them. Therefore, colleges and universities must pay attention to lay a good language foundation for students in future school-running. Ask Chinese students learn some basic Russian, and require Russian teachers be able to speak some Chinese.

\section{Accurately Grasp the Market Demand}

Under the background of Sino-Russian joint schoolrunning, the teaching of physical education major in colleges and universities should fully understand the market needs. We cannot teach blindly, which will result students having no competitiveness after their graduation. And this will not only affect the graduates' career development, but also affect the long-term development of Sino-Russian joint school-running.

\section{E. Innovate the Cultivation Method}

At present, most of the specialties in the colleges jointly run by China and Russia adopt the $2+2$ cultivation mode, dividing student's study time averagely at home and abroad, namely two years at home country, and two years abroad. Later, after a period of practice, it is found that disadvantages also exist in it, and reform and innovation are also needed. As for physical education major, the $1+3$ cultivation mode can be used, namely to learn Russian and professional knowledge for 1 year, and accept profession education for 3 years in Russia. As for the students with poor Russian foundation, 1 year of preparatory study can be added based on $1+3$ mode.

\section{F. Pay Attention to Process Evaluation, Emphasize Physical and Mental Health}

At present, China's physical education shall emphasize students' all-round development of body and mind, and it cannot be just limited to the physical quality enhancement. In physical education evaluation, the colleges jointly run by China and Russia shall pay sufficient attention to progress process and learning process without just focus on the learning effect. Try to arouse students' enthusiasm in learning and exercising, to improve the quality of students' physical and mental health.

To sum up, the Sino-Russian joint school-running is conducive to the introduction of Russian high quality education resources and promotion of reform and development of China's physical education; it is advantageous to the formation of diversified and balanced international schoolrunning pattern in China. To improve the quality and level of Sino-Russian joint school-running and promote the development of physical education in colleges and universities, the physical education concept shall be changed, and adopt the scientific physical education mode, lay a good language foundation, accurately grasp the market demand, innovate the cultivation mode, pay attention to process evaluation, and emphasis on physical and mental health. 


\section{REFERENCES}

[1] Li Changzhu, Zhao Weiming. Discussion on Value of Introducing Skiing into College Physical Education [J]. Science and Technology of Stationery \& Sporting Goods. 2012(04).

[2] Liu Qi, Wu Tienan. Comparative Study on Professional Curriculum Setting in Sino-Russian Physical Education [J]. Journal of Heihe University. 2010(03).

[3] Song Liquan. Current Situation of Sino-Russian Joint School-Running in Northern Xinjiang and Reflection on It [J]. China Higher Education Research. 2010(02).

[4] Liu Qiao. Discussion on Significance and Development Pattern of SinoRussian Joint School-Running [J]. Journal of Suihua University. 2009(04).

[5] Guo Jianwei. Study on Main Problems in Sino-Foreign Joint SchoolRunning and Countermeasures [D]. Northeast Normal University 2011. 